Karakteristik Fisik, Kimia dan Organoleptik Jelly Cincau Hitam - Christanti, dkk Jurnal Pangan dan Agroindustri Vol.7 No.1: 49-59, Januari 2019

\title{
KARAKTERISTIK FISIK, KIMIA, DAN ORGANOLEPTIK JELLY CINCAU HITAM (Mesona palustris BI) (KAJIAN KONSENTRASI SIMPLISIA CINCAU HITAM DAN KONSENTRASI KARAGENAN)
}

\section{Physical, Chemical and Organoleptic Black Cincau Jelly (Mesona Palustris BI) (Study of Black Cincau Simplicia Consentration and Carageenan Consentration)}

\author{
Rositha Adryana Christanti*, Wahono Hadi Susanto, Endrika Widyastuti \\ Jurusan Teknologi Hasil Pertanian, FTP Universitas Brawijaya Malang \\ JI. Veteran, Malang 65145 \\ *Penulis Korespondensi, Email: rosithaadryana@gmail.com
}

\begin{abstract}
ABSTRAK
Simplisia cincau hitam memiliki banyak manfaat untuk mencegah berbagai penyakit sehingga masyarakat mulai membudidayakannya. Jenis pengolahan produk ini masih sedikit sehingga perlu adanya diversifikasi produk. Tujuan dari penelitian ini untuk mengetahui pengaruh dan interaksi antara konsentrasi simplisia dan konsentrasi karagenan pada pembuatan jelly cincau hitam terhadap sifat fisik, kimia, dan organoleptik jelly cincau hitam. Rancangan penelitian yang digunakan adalah Rancangan Acak Kelompok (RAK) yang disusun secara faktorial dengan 2 faktor, yaitu konsentrasi simplisia dan konsentrasi karagenan.

Hasil penelitian menunjukan, interaksi antara konsentrasi simplisia dan konsentrasi karagenan berpengaruh nyata terhadap aktivitas antioksidan, tekstur, nilai kecerahan $\left(L^{*}\right)$, kemerahan $\left(A^{*}\right)$ dan kekuningan $\left(B^{*}\right)$. Pada analisis perlakuan terbaik metode Zeleny didapatkan perakuan terbaik pengujian kimia dengan konsentrasi simplisia $1.5 \%$ dan konsentrasi karagenan $0.5 \%$, pengujian fisik perlakuan terbaik terletak pada konsentrasi simplisia $1.5 \%$ dan konsentrasi karagenan $1 \%$, dan pada uji organoleptik perlakuan terbaik didapatkan dengan konsentrasi simplisia $1 \%$ dan konsentrasi karagenaan $1 \%$.
\end{abstract}

Kata kunci: Cincau hitam, Ekstrak cincau, Jelly

\begin{abstract}
Black cincau's simplicia has many benefits to prevent various diseases, so people start to cultivate. There needs to be diversification of processed cincau to increase the diversity of product. The purpose of this study was to determine the effect and interaction between leaf concentration and carrageenan concentration on black cincau jelly on the physical, chemical, and organoleptic properties. The research design used was Randomized Complete Block Design which was arranged factorially with 2 factors which are leaf concentration and carrageenan concentrations.

The results showed that, interaction between leaf concentration and carrageenan concentration had significant effect on antioxidant activity, texture, brightness value (L), redness $(A)$ and yellowish (B). In the best treatment analysis of Zeleny method (1982) obtained best chemical testing on jelly with $1,5 \%$ leaf concentration and $0.5 \%$ carrageenan concentration, best physical testing on jelly with $1,5 \%$ leaf concentration and $1 \%$ carrageenan concentration, and on organoleptic test the best treatment was found on jelly with $1 \%$ leaf concentration and $1 \%$ caragenaan concentration.
\end{abstract}

Keywords: Black cincau, Cincau extract, Jelly 


\section{PENDAHULUAN}

Tanaman cincau hitam (Mesona palustris $B L$ ) merupakan tanaman yang dapat tumbuh dengan baik di dataran rendah sampai dataran tinggi hingga ketinggian $2.300 \mathrm{mdpl}$ (Miftakhurohmah, 2006). Pada penelitian sebelumnya ditemukan bahwa cincau hitam dapat mengobati tekanan darah tinggi, diabetes, dan penyakit gangguan hati dikarenakan kandungan senyawa fenol yang ada pada cincau hitam berkontribusi pada aktivitas antioksidan dan memberi efek scavenging pada radikal bebas. Aktivitas antioksidan dari cincau hitam pada konsentrasi $50 \mathrm{mg} / \mathrm{ml}$ (98.9\%) lebih kuat dibandingkan $50 \mathrm{mg} / \mathrm{ml} \alpha$ tocopherol (78\%) (Wahyono, 2015). Peluang usaha agribisnis cincau hitam masih luas dengan potensi pasar yang cukup baik. Perlu adanya diversifikasi olahan cincau untuk meningkatkan keragaman jenis olahan sehingga dapat bersaing di pasaran. Salah satu cara untuk menyelesaikan permasalahan ini dengan membuat produk ekstrak cincau menjadi jelly cincau.

Jelly dipilih karena pembuatannya yang mudah dan disukai oleh banyak kalangan masyarakat. Selain itu cincau hitam dikenal memiliki kadungan antioksidan yang tinggi sehingga dapat meningkatkan nilai produk jelly cincau hitam sebagai produk pangan fungsional. Dalam pembuatan jelly, tingkat keasaman, gula, dan pektin merupakan faktor yang sangat mempengaruhi tekstur serta proses pembentukan gel dari produk jelly (Wibowo, 2009). Pada pembuatan jelly cincau hitam melibatkan proses ekstraksi simplisia cincau hitam sebagai bahan baku utama.

Ekstraksi dilakukan dengan proporsi penambahan simplisia dan air dalam jumlah tertentu, selanjutnya akan ditambahkan karagenan sebagai bahan pembentuk gel. Rasio simplisia banding air pada proses ekstraksi menentukan total senyawa kimia yang larut dan mempengaruhi sifat fisik, kimia, dan organoleptik jelly cincau hitam. Semakin banyak simplisia yang diekstrak maka viskositas ekstrak cincau yang dihasilkan akan semakin tinggi sehingga tidak membutuhkan penambahan karagenan yang terlalu banyak. Namun semakin sedikit simplisia yang diekstrak maka viskositas ekstrak cincau rendah sehingga membutuhkan penambahan karagenan dalam jumlah banyak untuk menghasilkan karakteristik jelly yang diinginkan. Hal ini dikarenakan terdapat komponen pembentuk gel yang terekstrak pada ekstrak simplisia yang mampu meningkatkan viskositas ekstrak.

Melalui penelitian ini diharapkan mampu mengetahui pengaruh dan interaksi antara konsentrasi simplisia dan konsentrasi karagenan pada pembuatan jelly cincau hitam terhadap sifat fisik, kimia, dan organoleptik jelly cincau hitam. Penelitian ini diharapkan mampu memberi manfaat kepada penulis dan masyarakat pada umumnya. Masyarakat dapat mengetahui inovasi produk jelly cincau hitam dengan proporsi bahan yang tepat. Selain itu pemanfaatan cincau hitam sebagai bahan baku dapat meningkatkan nilai ekonomi. Disisi lain produk ini merupakan pangan fungsional yang mampu mencegah penyakit degeneratif bagi masyarakat.

\section{BAHAN DAN METODE}

\section{Bahan}

Bahan yang digunakan dalam penelitian ini adalah simplisia cincau hitam (Mesona palustris $B L$ ) yang didapat langsung dari kabupaten Magetan, gula pasir, asam sitrat (gajah), serta kappa karaginan (Misketo). Bahan-bahan yang diperlukan untuk analisis kimia, antara lain akuades, buffer $\mathrm{pH} 4$ dan 7, folin, $\mathrm{Na}$ bikarbonat, $\mathrm{HCl}, \mathrm{NaOH} 0.1 \mathrm{~N}$, indikator pp, asam asetat, larutan DPPH $0.2 \mathrm{mM}, \mathrm{CaCl}_{2}$, dan $\mathrm{AgNO}_{3}$.

\section{Alat}

Alat-alat yang digunakan dalam pembuatan Jelly Cincau Hitam adalah sendok stainless steel, baskom, thermometer, kompor, panci stainless steel, pengaduk, dan cup jelly. Alat-alat yang digunakan untuk analisis fisik dan kimia meliputi timbangan analitik (Denver Instrument M-310), pH meter (Ezido PL. 600), color reader (Minolta CR-10 Jepang), kertas 
saring, kain saring, kertas saring whatman no 4, glassware (Pyrex), dan spektrofotometer (unico UV-2100).

\section{Desain Penelitian}

Metode penelitian ini menggunakan Rancangan Acak Kelompok Faktorial (RAKF) yang disusun secara faktorial dengan 2 faktor, yaitu konsentrasi simplisia dan konsentrasi karagenan. Faktor 1 terdiri dari 3 level dan faktor 2 terdiri dari 3 level, sehingga menghasilkan perlakuan 9 kombinasi dan dilakukan pengulangan sebanyak 3 kali sehingga diperoleh 27 satuan percobaan. Data hasil pengamatan menggunakan Rancangan Acak Kelompok Faktorial (RAKF) dianalisis secara statistik dengan menggunakan ANOVA (Analysis of Variance). Apabila terdapat pengaruh nyata pada kedua perlakuan dilakukan uji lanjut DMRT (Duncan Multiple Range Test) 5\% atau uji BNT (Beda Nyata Terkecil) 5\%. Data hasil uji organoleptik dilakukan dengan uji Hedonic Scale Scoring menggunakan uji analisis statistik Friedman. Kemudian pemilihan perlakuan terbaik dengan menggunakan metode indeks efektifitas.

\section{Tahapan Penelitian}

Simplisia cincau hitam kering disortasi dari debu dan kotoran lainnya kemudian dicuci bersih untuk menghilangkan debu / tanah yang menempel pada simplisia. Kemudian simplisia cincau ditimbang sesuai proporsi dan ditambahkan air sesuai proporsi lalu dipanaskan pada suhu $90-100^{\circ} \mathrm{C}$ selama 5 menit. Selanjutnya ekstrak diding inkan hingga suhu mencapai $40^{\circ} \mathrm{C}$ lalu simplisia diremas - remas selama 3 menit. Hal ini bertujuan agar komponen - komponen larut air seperti komponen pembentuk gel dan fenolik dapat terekstrak sempurna. Kemudian ekstrak cincau hitam disaring menggunakan kain saring untuk memisahkan ekstrak dengan simplisia cincau hitam dan ekstrak cincau hitam siap untuk digunakan (Modifikasi Farida, 2006)

Setelah pembuatan ekstrak cincau hitam, ekstrak siap digunakan untuk proses selanjutnya yaitu pembuatan jelly cincau hitam. Pertama ekstrak cincau hitam yang sudah siap diambil sesuai kebutuhan kemudian ditambahkan karagenan sesuai proporsi, asam sitrat $0.1 \%$, dan gula $25 \%$ kemudian diaduk hingga merata. Lalu ekstrak dimasak pada suhu 90 $100^{\circ} \mathrm{C}$ selama 3 menit sambil terus diaduk agar jelly tidak menggumpal. Setelah itu jelly dituangkan ke dalam cup jelly dan didinginkan hingga jelly memadat dan mencapai suhu ruangan (Modifikasi Padmaningrum, 2013). Jelly cincau hitam siap untuk dianalisis karakteristik kimia, fisik dan organoleptik

\section{HASIL DAN PEMBAHASAN}

\section{Analisis Bahan Baku}

Analisis bahan baku bertujuan untuk mengetahui kondisi awal bahan baku yang akan digunakan dalam pembutan produk jelly cincau hitam. Bahan baku utama yang digunakan pada penelitian ini yaitu bagian simplisia cincau hitam jenis Mesona Palustris Bl yang diperoleh dari daerah Magetan.

Tabel 1. Perbandingan hasil analisis bahan baku simplisia cincau hitam dengan literatur

\begin{tabular}{lcc}
\hline Parameter & Hasil Analisis & Literatur \\
\hline Kadar air & $15.47 \% \pm 0.12$ & $15.26 \%^{(\mathrm{a})}$ \\
Antioksidan & $81.03 \% \pm 0.56$ & $68.60 \%^{(\mathrm{b})}$ \\
Kadar fenol & $39.71 \% \pm 0.78$ & $43.47 \%^{(\mathrm{b})}$ \\
pH & $4.5 \pm 0.06$ & - \\
Warna : & & - \\
Kecerahan (L) & $35.40 \pm 0.31$ & - \\
Kemerahan (A) & $10.97 \pm 0.41$ & - \\
Kekuningan (B) & $10.77 \pm 0.43$ & (b) Lai and Chao (2001)
\end{tabular}




\section{Nilai $\mathrm{pH}$}

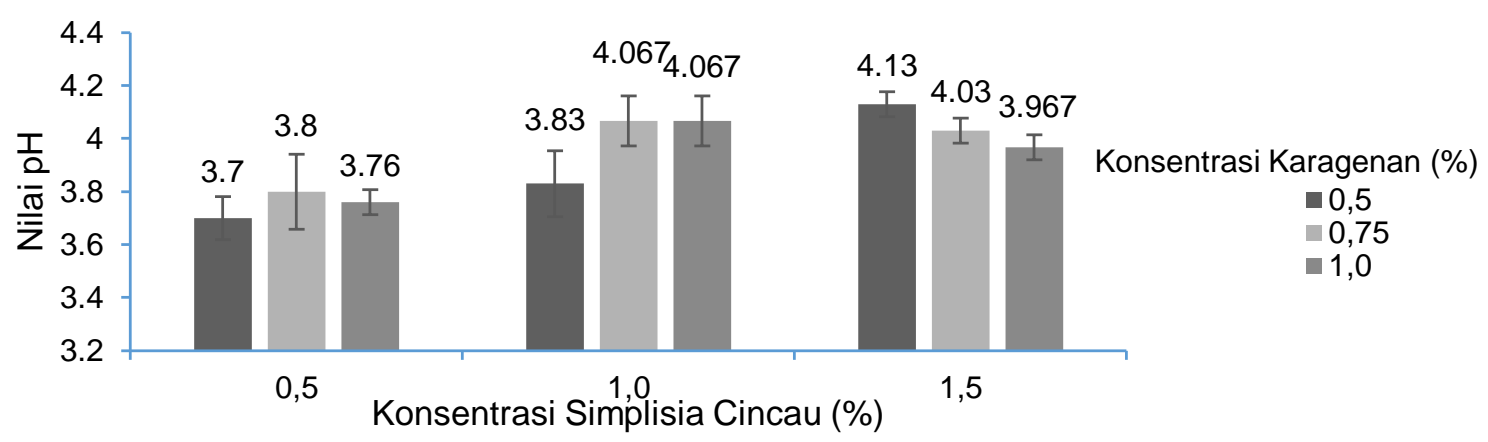

Gambar 1. Grafik rerata pH jelly cincau hitam akibat perbedaan konsentrasi simplisia dan konsentrasi karagenan

Hasil analisis sidik ragam menunjukkan bahwa perlakuan konsentrasi simplisia memberikan pengaruh nyata $(\alpha=0.05)$, namun perlakuan karagenan dan interaksi kedua perlakuan tidak berpengaruh nyata terhadap rerata $\mathrm{pH}$ jelly cincau hitam. Rerata $\mathrm{pH}$ jelly cincau hitam akibat perlakuan konsentrasi simplisia diuji BNT 5\%. Masing-masing konsentrasi simplisia memberikan pengaruh yang berbeda nyata terhadap produk jelly cincau hitam. Semakin tinggi konsentrasi simplisia yang diekstraksi maka akan semakin meningkat nilai $\mathrm{pH}$ produk jelly cincau hitam. Konsentrasi simplisia sebanyak $1.5 \%$ dan $1 \%$ memiliki rata-rata tertinggi dengan nilai $\mathrm{pH} 4.04$ dan 3.98 sedangkan konsentrasi simplisia $0.5 \%$ memiliki ratarata terendah dengan nilai $\mathrm{pH}$ 3.75. Menurut Winarno (2002) simplisia cincau hitam memiliki sejumlah asam organik dalam jumlah yang tidak terlalu banyak namun berkontribusi terhadap penurunan nilai $\mathrm{pH}$ minuman. Sehingga asam-asam organik yang terkandung akan menurunkan nilai $\mathrm{pH}$ dengan cara melepaskan ion $\mathrm{H}^{+}$. Menurut anonim (2002) bahan pengental yang ditambahkan khususnya karagenan adalah produk yang memiliki pH basa yaitu 9.5-10.5 sehingga dengan penambahan gelling agent akan menetralkan asam-asam organik yang terdapat pada bahan dan $\mathrm{pH}$ bahan akan semakin meningkat seiring dengan meningkatnya konsentrasi gelling agent yang ditambahkan.

\section{Kadar Antioksidan}

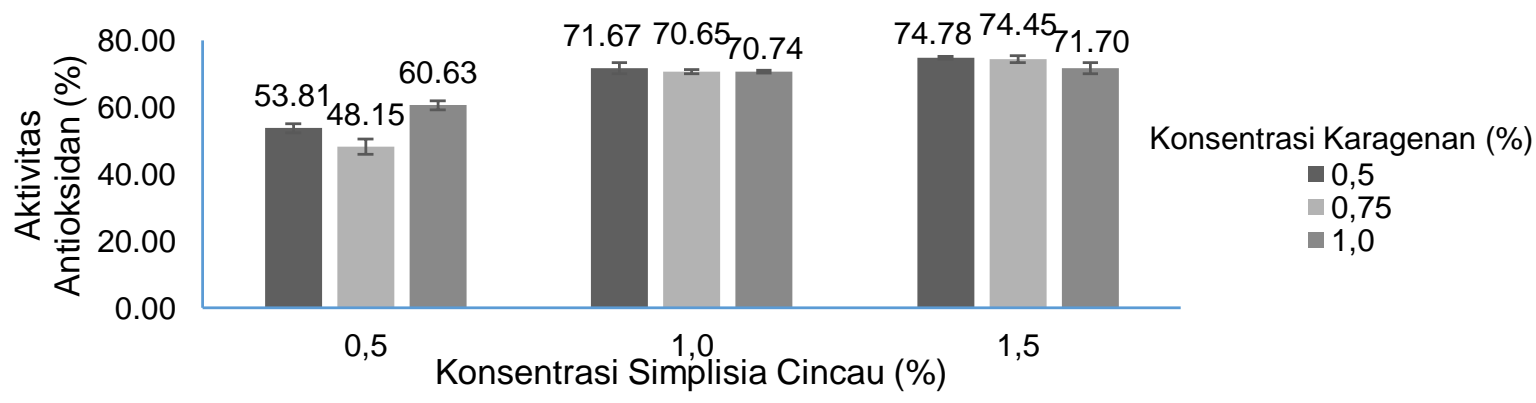

Gambar 2. Grafik rerata aktivitas antioksidan jelly cincau hitam akibat perbedaan konsentrasi simplisia dan konsentrasi karagenan

Hasil analisis sidik ragam menunjukkan bahwa perlakuan konsentrasi simplisia, konsentrasi penambahan karagenan dan interaksi antara kedua perlakuan memberikan pengaruh nyata $(\alpha=0.05)$ terhadap rerata antioksidan jelly cincau hitam. Rerata antioksidan jelly cincau hitam akibat perlakuan konsentrasi simplisia dan konsentrasi karagenan diuji DMRT 5\%. Hasil rerata aktivitas antioksidan jelly cincau hitam akibat perlakuan konsentrasi simplisia dan konsentrasi karagenan. Seperti yang terlihat pada tabel semakin tinggi konsentrasi simplisia maka semakin tinggi aktivitas antioksidan. Aktivitas antioksidan paling 
rendah dihasilkan oleh kombinasi perlakuan konsentrasi simplisia $0.5 \%$ dan konsentrasi karagenan $0.75 \%$. Sedangkan aktivitas antioksidan tertinggi dihasilkan oleh kombinasi perlakuan konsentrasi simplisia $1 \%$ dengan karagenan $0.5 \%$, konsentrasi simplisia $1 \%$ dengan karagenan 1\%, konsentrasi simplisia $1.5 \%$ dan konsentrasi karagenan $0.5 \%$, konsentrasi simplisia 1.5\% dan konsentrasi karagenan $0.75 \%$, dan konsentrasi simplisia $1.5 \%$ dan konsentrasi karagenan 1\%. Menurut Hung dan Yen (2002), bahwa ekstrak cincau hitam memiliki aktivitas antioksidan yang kuat akibat adanya senyawa-senyawa fenol. Menurut Gunstone and Padley (1997), besarnya aktivitas antioksidan dipengaruhi oleh kandungan senyawa fenol dari tanaman tersebut. Kelompok senyawa polifenol mampu mengikat ion-ion radikal bebas sehingga tidak berbahaya bagi tubuh.

\section{Total Fenol}

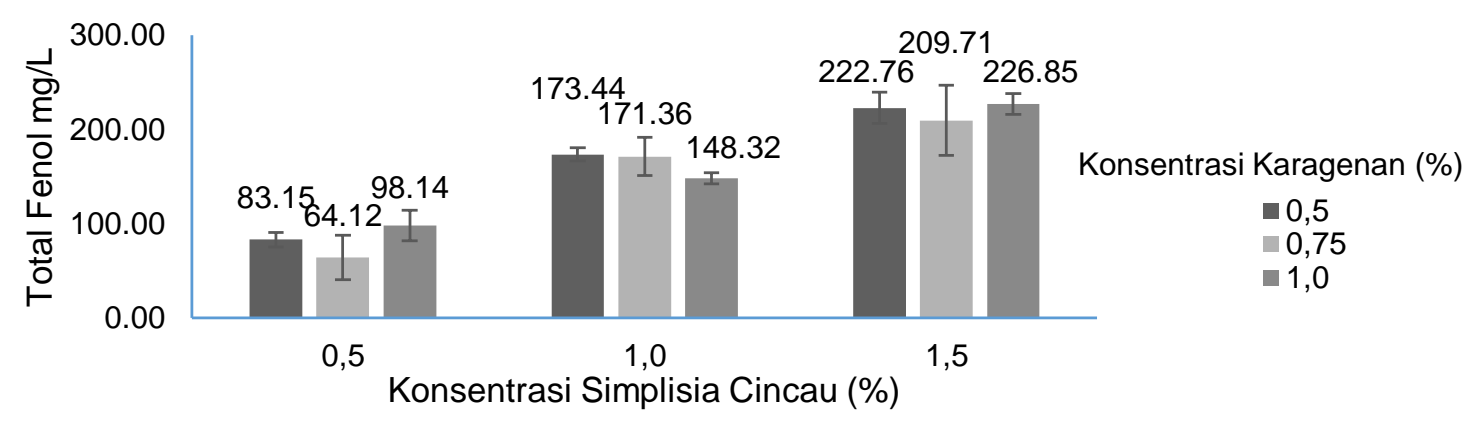

Gambar 3. Grafik rerata total fenol jelly cincau hitam akibat perbedaan konsentrasi simplisia dan konsentrasi karagenan

Hasil analisis sidik ragam menunjukkan bahwa perlakuan konsentrasi simplisia memberikan pengaruh nyata $(\alpha=0.05)$, namun perlakuan penambahan konsentrasi karagenan dan interaksi kedua perlakuan tidak berpengaruh nyata terhadap rerata total fenol jelly cincau hitam. Rerata total fenol jelly cincau hitam akibat perlakuan konsentrasi simplisia diuji BNT $5 \%$. Semua konsentrasi simplisia memberikan pengaruh berbeda nyata terhadap produk jelly cincau hitam. Dapat dilihat juga semakin tinggi konsentrasi simplisia cincau hitam yang diekstraksi maka akan semakin meningkat nilai total fenol pada produk jelly cincau hitam. Hal ini membuktikan bahwa di dalam simplisia cincau hitam mengandung senyawa fenolik yang tinggi. Senyawa fenol ini mampu mengikat ion-ion radikal bebas sehingga tidak berbahaya bagi tubuh. Menurut Tasia dan Widyaningsih (2014) kandungan senyawa fenol yang ada pada cincau hitam berkontribusi pada aktivitas antioksidan den efek scavenging pada radikal bebas.

\section{Total Pektin}

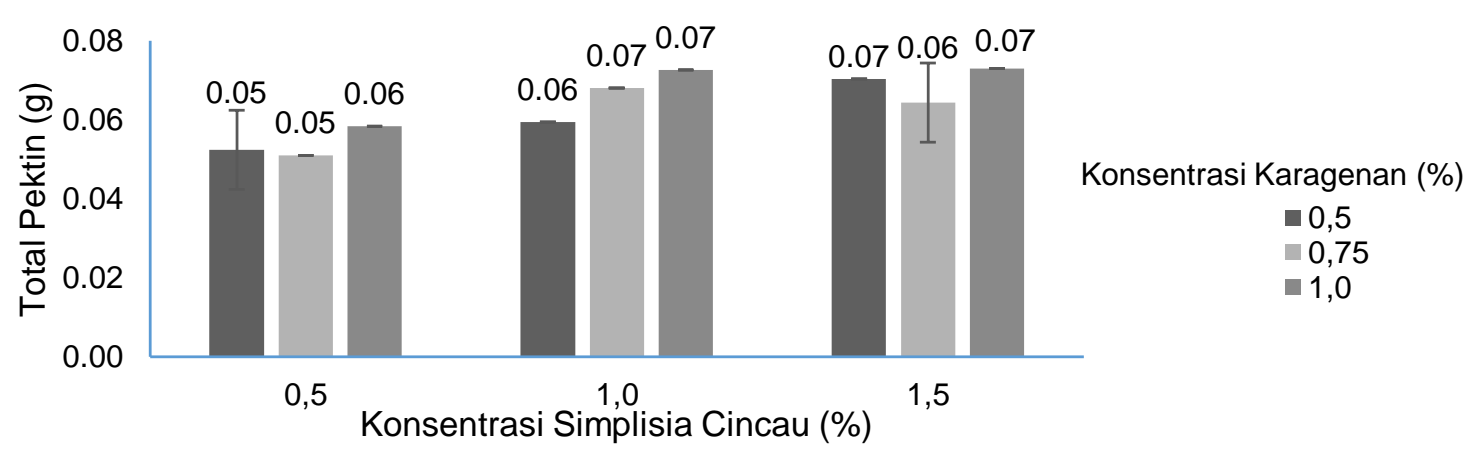

Gambar 4. Grafik rerata total pektin jelly cincau hitam akibat perbedaan konsentrasi simplisia dan konsentrasi karagenan 
Hasil analisis sidik ragam menunjukkan bahwa perlakuan konsentrasi simplisia memberikan pengaruh nyata $(\alpha=0.05)$, namun konsentrasi karagenan dan interaksi kedua perlakuan tidak berpengaruh nyata terhadap rerata total pektin jelly cincau hitam. Rerata total pektin jelly cincau hitam akibat perlakuan konsentrasi simplisia diuji BNT 5\%. Semakin tinggi konsentrasi simplisia cincau hitam yang diekstraksi maka akan semakin meningkat nilai total pektin pada produk jelly cincau hitam. Konsentrasi simplisia sebanyak $1.5 \%$ memiliki rata-rata tertinggi dengan nilai total pektin $0.06 \mathrm{~g}$ sedangkan konsentrasi simplisia $0.5 \%$ memiliki ratarata terendah dengan nilai total pektin sebesar $0.05 \mathrm{~g}$. Menurut Nuraini (2000) ekstrak cincau hitam mengandung komponen hidrokoloid yang berfungsi sebagai pembentuk gel/KPG.

\section{Nilai Tekstur}

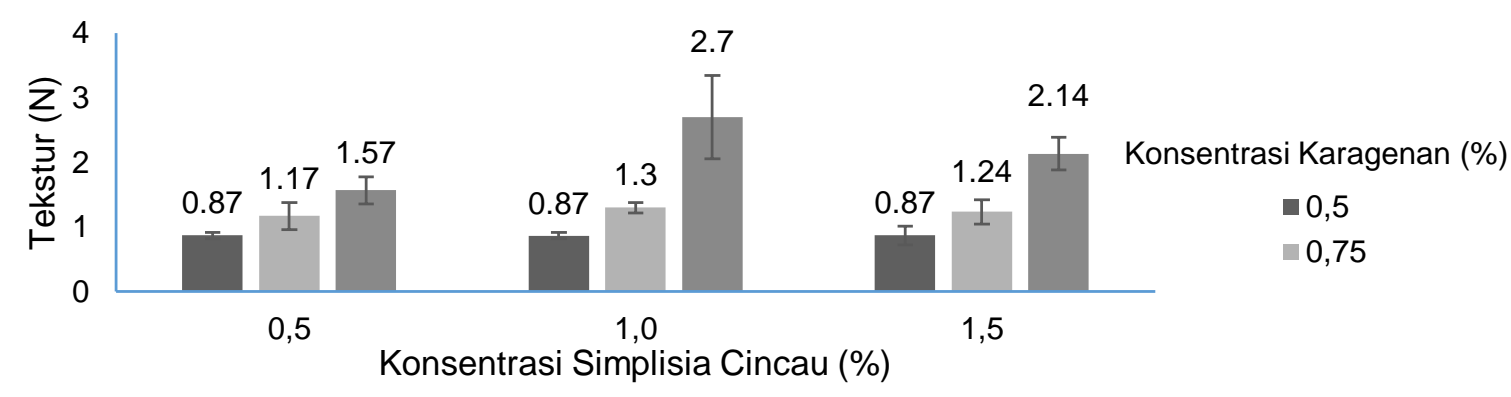

Gambar 5. Grafik rerata tekstur jelly cincau hitam akibat perbedaan konsentrasi simplisia dan konsentrasi karagenan

Hasil analisis sidik ragam menunjukkan bahwa perlakuan konsentrasi simplisia, konsentrasi penambahan karagenan dan interaksi kedua perlakuan memberikan pengaruh nyata $(\alpha=0.05)$ terhadap rerata tekstur jelly cincau hitam. Rerata tekstur jelly cincau hitam akibat perlakuan konsentrasi simplisia diuji DMRT 5\%. Semakin tinggi konsentrasi simplisia dan konsentrasi karagenan yang digunakan maka tekstur jelly cincau hitam juga akan semakin meningkat. Tekstur jelly yang paling lunak terdapat pada kombinasi perlakuan konsentrasi simplisia $0.5 \%$ dan konsentrasi karagenan $0.5 \%$, konsentrasi simplisia $1 \%$ dan konsentrasi karagenan $0.5 \%$, konsentrasi simplisia $0.5 \%$ dan konsentrasi karagenan $0.75 \%$, konsentrasi simplisia $1 \%$ dan konsentrasi karagenan $0.75 \%$. Sedangkan tekstur jelly cincau hitam yang paling keras terdapat pada kombinasi perlakuan konsentrasi simplisia $1 \%$ dan konsentrasi karagenan 1\%, konsentrasi simplisia 1.5\% dan konsentrasi karagenan $1 \%$. Hal ini dapat disebabkan karena tingginya kadar komponen pembentuk gel yang didapat dalam ekstrak simplisia cincau hitam dan kadar karagenan dalam produk.

\section{Nilai Sineresis}

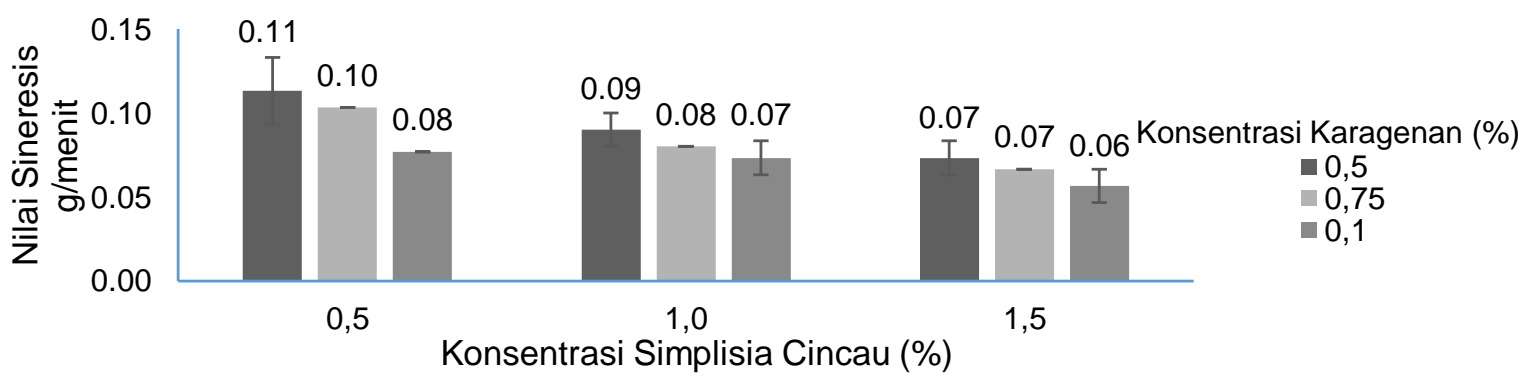

Gambar 6. Grafik rerata nilai sineresis jelly cincau hitam akibat perbedaan konsentrasi simplisia dan konsentrasi karagenan

Hasil analisis sidik ragam menunjukkan bahwa perlakuan konsentrasi simplisia dan konsentrasi penambahan karagenan memberikan pengaruh nyata $(\alpha=0.05)$, namun interaksi 
kedua perlakuan tidak berpengaruh nyata terhadap rerata nilai sineresis jelly cincau hitam. Rerata nilai sineresis jelly cincau hitam akibat perlakuan konsentrasi simplisia dan konsentrasi karagenan diuji BNT 5\%. Setiap konsentrasi simplisia memberikan pengaruh berbeda nyata terhadap produk jelly cincau hitam, semakin tinggi konsentrasi simplisia cincau hitam yang diekstraksi maka nilai sineresis produk jelly cincau hitam akan semakin menurun. Semakin tinggi konsentrasi karagenan yang ditambahkan maka nilai sineresis produk jelly cincau hitam akan semakin menurun pula. Hal ini dapat disebabkan karena semakin tinggi konsentrasi simplisia yang diekstrak dan penambahan konsentrasi karagenan maka akan semakin tinggi kandungan komponen pembentuk gel yang teresktrak sehingga meningkatkan kekuatan gel pada jelly cincau hitam.

\section{Kecerahan}

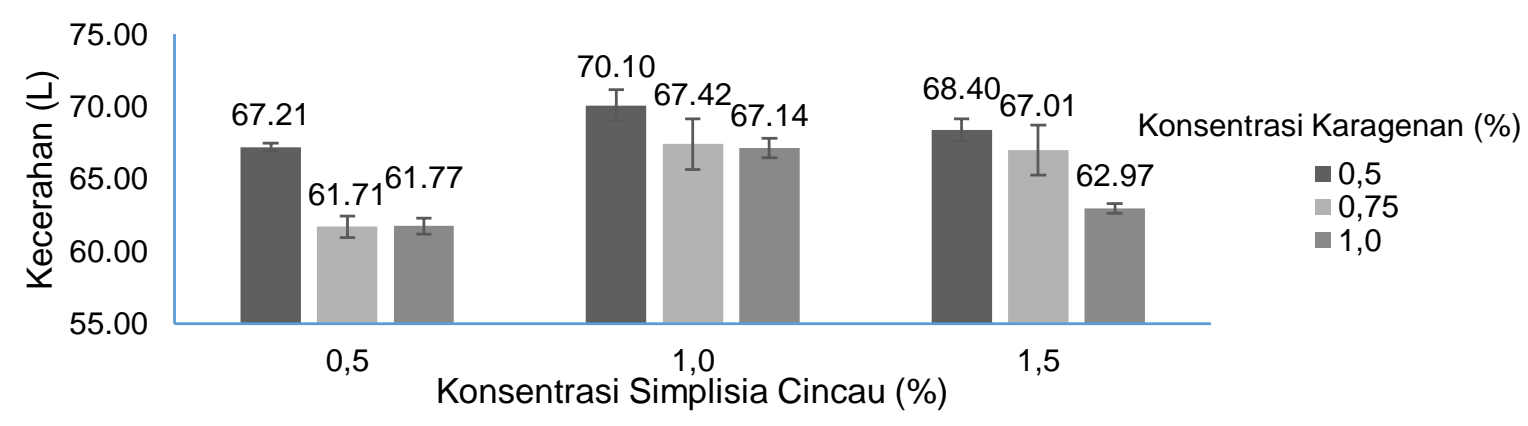

Gambar 7. Grafik rerata nilai kecerahan (L) jelly cincau hitam akibat perbedaan konsentrasi simplisia dan konsentrasi karagenan

Rerata nilai kecerahan (L) jelly cincau hitam akibat perlakuan konsentrasi simplisia dan konsentrasi karagenan diuji DMRT 5\%. Semakin tinggi konsentrasi simplisia dan konsentrasi karagenan yang digunakan maka nilai kecerahan jelly cincau hitam akan semakin menurun. Nilai kecerahan (L) jelly cincau hitam yang paling tinggi terdapat pada kombinasi perlakuan dengan notasi a yaitu konsentrasi simplisia $0.5 \%$ dan konsentrasi karagenan $0.75 \%$, konsentrasi simplisia $0.5 \%$ dan konsentrasi karagenan $1 \%$, konsentrasi simplisia $1.5 \%$ dan konsentrasi karagenan $1 \%$. Sedangkan nilai kecerahan (L) jelly cincau hitam yang paling rendah terdapat pada kombinasi perlakuan dengan notasi c yaitu konsentrasi simplisia $1 \%$ dan konsentrasi karagenan $0.5 \%$. Semakin tinggi konsentrasi simplisia yang diekstrak maka warna jelly cincau hitam akan semakin gelap karena semakin banyak senyawa polar seperti polifenol dan flavonoid yang terekstrak, termasuk komponen pembentuk gel (KPG) pada simplisia cincau hitam yang cenderung bersifat polar dan berwarna gelap.

\section{Kemerahan}

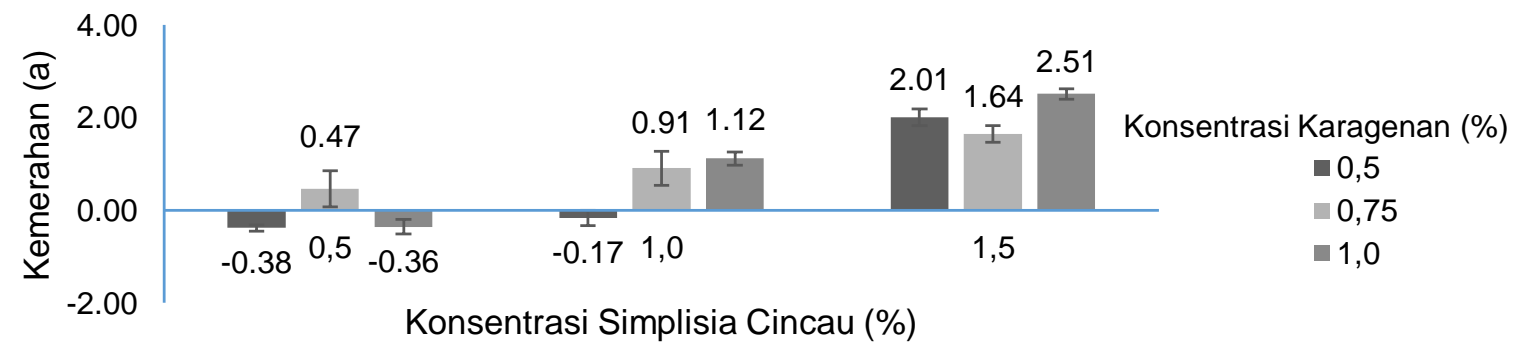

Gambar 8. Grafik rerata nilai kemerahan (a) jelly cincau hitam akibat perbedaan konsentrasi simplisia dan konsentrasi karagenan

Hasil analisis sidik ragam menunjukkan bahwa perlakuan konsentrasi simplisia, konsentrasi penambahan karagenan dan interaksi antara kedua perlakuan memberikan 
pengaruh nyata $(\alpha=0.05)$ terhadap rerata nilai kemerahan (a) jelly cincau hitam. Rerata nilai kemerahan (a) jelly cincau hitam akibat perlakuan konsentrasi simplisia dan konsentrasi karagenan dengan uji DMRT 5\%. Semakin tinggi konsentrasi simplisia dan konsentrasi karagenan yang digunakan maka nilai kemerahan jelly cincau hitam akan semakin meningkat. Nilai kemerahan (a) jelly cincau hitam yang paling rendah terdapat pada kombinasi perlakuan dengan notasi a yaitu konsentrasi simplisia $0.5 \%$ dan konsentrasi karagenan $0.5 \%$, konsentrasi simplisia $0.5 \%$ dan konsentrasi karagenan $1 \%$, konsentrasi simplisia $1 \%$ dan konsentrasi karagenan $0.5 \%$. Sedangkan nilai kemerahan (a) jelly cincau hitam yang paling tinggi terdapat pada kombinasi perlakuan dengan notasi f yaitu konsentrasi simplisia $1.5 \%$ dan konsentrasi karagenan $0.5 \%$, konsentrasi simplisia 1,5\% dan konsentrasi karagenan $1 \%$.

\section{Kekuningan}

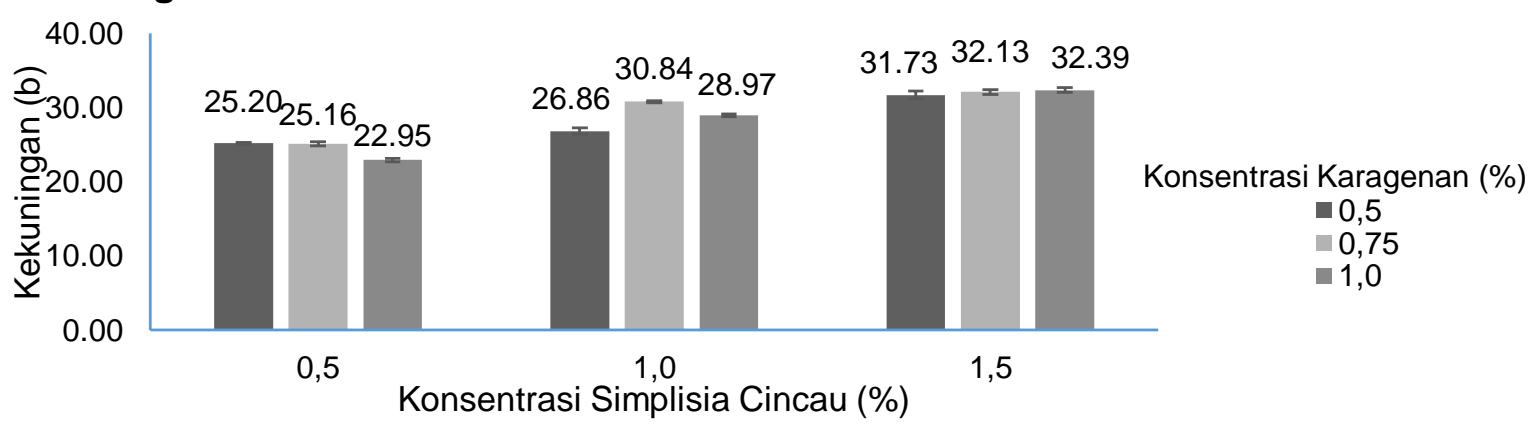

Gambar 9. Grafik rerata nilai kekuningan (b) jelly cincau hitam akibat perbedaan konsentrasi simplisia dan konsentrasi karagenan

Hasil analisis sidik ragam menunjukkan bahwa perlakuan konsentrasi simplisia, konsentrasi penambahan karagenan dan interaksi antara kedua perlakuan memberikan pengaruh nyata $(\alpha=0.05)$ terhadap rerata nilai kekuningan (b) jelly cincau hitam. Rerata nilai kekuningan (b) jelly cincau hitam akibat perlakuan konsentrasi simplisia dan konsentrasi karagenan diuji DMRT 5\%. Semakin tinggi konsentrasi simplisia dan konsentrasi karagenan yang digunakan maka nilai kekuningan jelly cincau hitam akan semakin meningkat. Nilai kekuningan (b) jelly cincau hitam yang paling rendah terdapat pada kombinasi perlakuan konsentrasi simplisia $0.5 \%$ dan konsentrasi karagenan $1 \%$. Sedangkan nilai kekuningan (b) jelly cincau hitam yang paling tinggi terdapat pada kombinasi perlakuan konsentrasi simplisia $1.5 \%$ dan konsentrasi karagenan $0.5 \%$, konsentrasi simplisia $1.5 \%$ dan konsentrasi karagenan $0.75 \%$, konsentrasi simplisia $1.5 \%$ dan konsentrasi karagenan $1 \%$.

\section{Analisis Organoleptik}

\subsection{Warna}

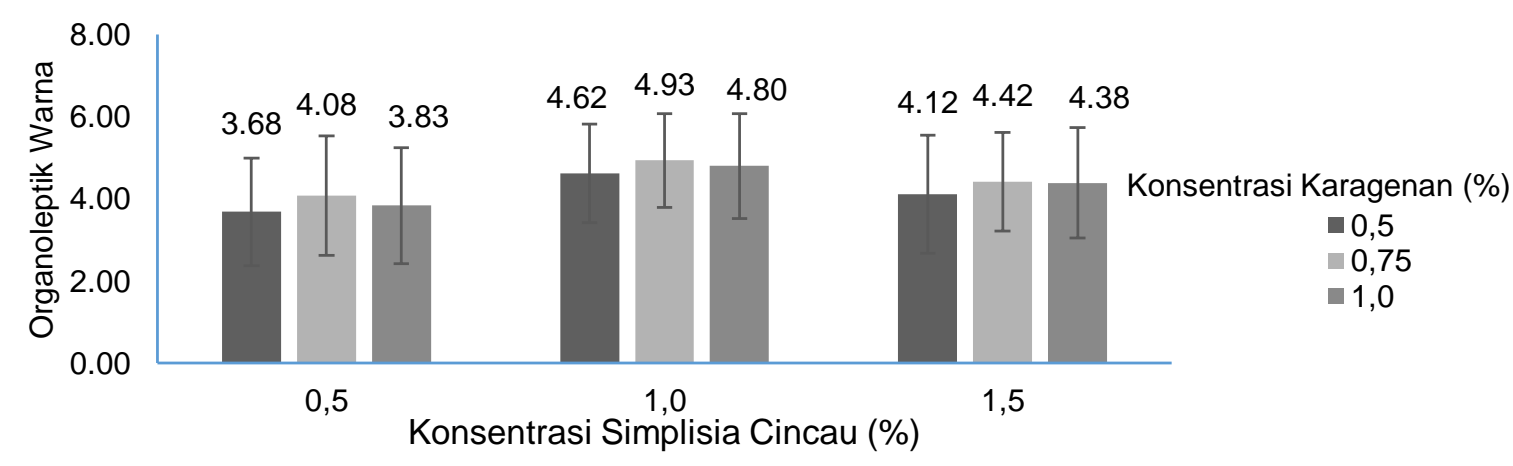

Gambar 10. Grafik rerata nilai organoleptik warna jelly cincau hitam akibat perbedaan konsentrasi simplisia dan konsentrasi karagenan 
Pada Gambar 10 terlihat panelis lebih menyukai warna jelly cincau hitam dengan konsentrasi simplisia $1 \%$ dibanding $0.5 \%$ dan $1.5 \%$. Hal ini dapat dikarenakan pada konsentrasi simplisia 1\% warna jelly terlihat tidak pucat namun juga tidak terlalu gelap. Sedangkan untuk konsentrasi simplisia $0.5 \%$ warna jelly terlihat pucat dan untuk konsentrasi simplisia $1.5 \%$ warna jelly cincau hitam terlihat sedikit gelap. Hal ini dikarenakan semakin tinggi konsentrasi simplisia yang diekstrak maka warna jelly cincau hitam akan semakin gelap karena semakin banyak senyawa polar seperti polifenol dan flavonoid yang terekstrak, termasuk komponen pembentuk gel (KPG) pada simplisia cincau hitam yang cenderung bersifat polar dan berwarna gelap.

\subsection{Rasa}

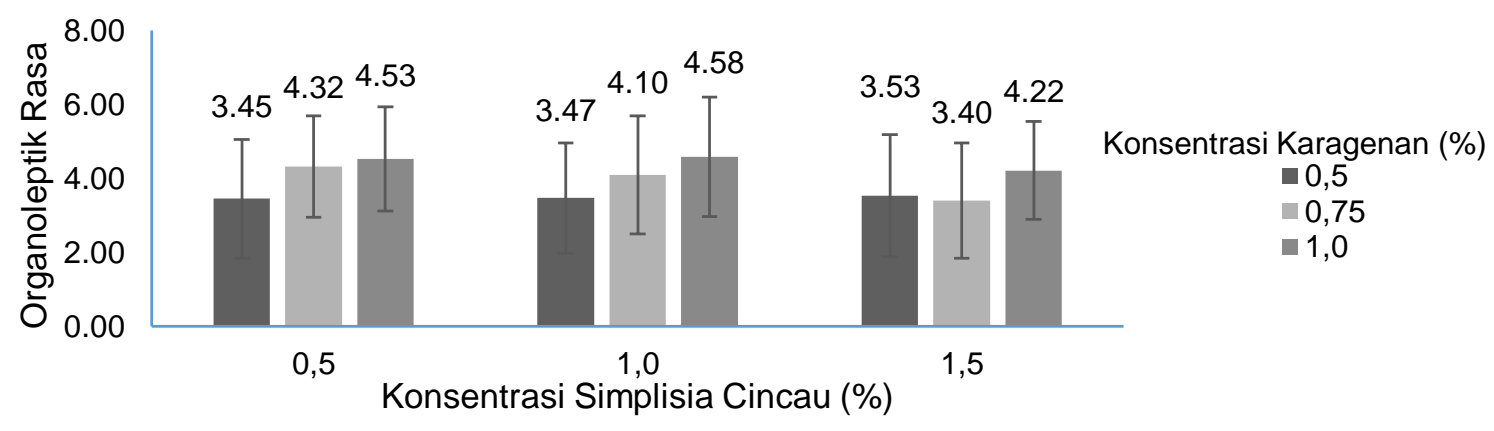

Gambar 11. Grafik rerata nilai organoleptik rasa jelly cincau hitam akibat perbedaan konsentrasi simplisia dan konsentrasi karagenan

Pada Gambar 11 terlihat panelis lebih menyukai rasa jelly cincau hitam dengan konsentrasi simplisia $1 \%$ dibanding $0.5 \%$ dan $1.5 \%$. Hal ini dapat dikarenakan pada konsentrasi simplisia $1 \%$ rasa cincau hitam yang muncul tidak terlalu pahit namun masih terasa rasa khas cincau. Sedangkan untuk konsentrasi simplisia 1.5\% rasa sepat dari cincau terlalu dominan karena konsentrasi simplisia yang terlalu banyak, dan pada konsentrasi simplisia $0.5 \%$ rasa cincau terasa samar sehingga rasa asam dari penambahan asam sitrat dan manis dari penambahan gula yang mendominasi produk pada konsentrasi simplisia cincau $0.5 \%$.

\subsection{Aroma}

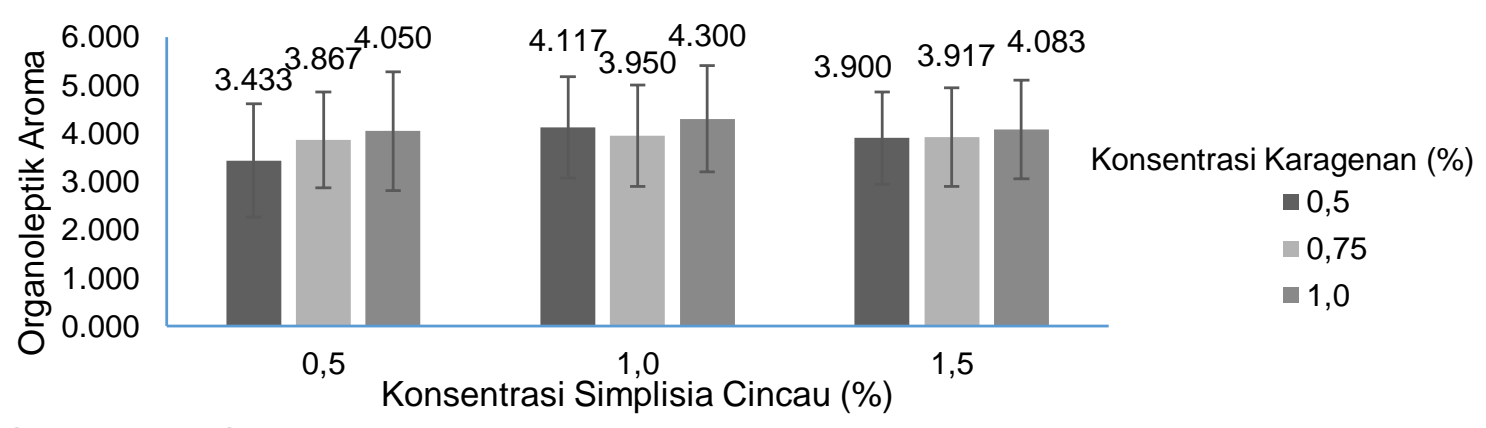

Gambar 12. Grafik rerata nilai organoleptik aroma jelly cincau hitam akibat perbedaan konsentrasi simplisia dan konsentrasi penambahan karagenan

Pada Gambar 12 terlihat panelis lebih menyukai aroma jelly cincau hitam dengan konsentrasi simplisia $1 \%$ dibanding $0.5 \%$ dan $1.5 \%$. Hal ini dapat dikarenakan pada konsentrasi simplisia 1\% aroma cincau hitam yang muncul tidak terlalu pekat (aroma khas cincau hitam) dibandingkan dengan konsentrasi simplisia $1.5 \%$, namun sebaliknya pada konsentrasi simplisia $0.5 \%$ aroma cincau hitam tidak tercium karena konsentrasi simplisia yang diekstrak kecil. Timbulnya aroma ini secara langsung maupun tidak langsung, selalu 
dihubungkan dengan terjadinya oksidasi senyawa polifenol yang terjadi saat proses ekstraksi dan pemasakan jelly cincau hitam kandungan senyawa volatil pada ekstrak cincau hitam akan menurun jika suhu yang digunakan terlalu tinggi.

\subsection{Tekstur}

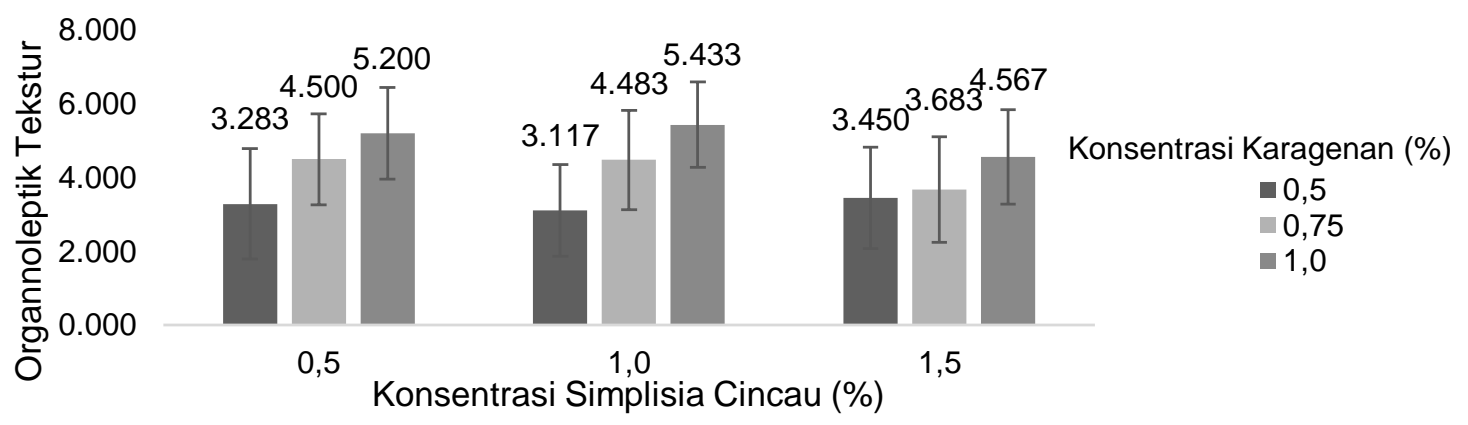

Gambar 13. Grafik rerata nilai organoleptik tekstur jelly cincau hitam akibat perbedaan konsentrasi simplisia dan konsentrasi penambahan karagenan

Pada Gambar 13 terlihat panelis lebih menyukai tekstur jelly cincau hitam dengan konsentrasi simplisia $1 \%$ dibanding $0.5 \%$ dan $1.5 \%$. Hal ini dapat dikarenakan pada konsentrasi simplisia 1\%, konsentrasi komponen pembentuk gel yang teresktrak sudah mencukupi untuk membentuk gel yang disukai oleh panelis tekstur gel tidak terlalu lembek dan tidak terlalu padat. Sedangkan untuk konsentrasi karagenan yang paling disukai panelis adalah konsentrasi karagenan 1\%. Hal ini dikarenakan pada konsentrasi karagenan $1 \%$ tekstur jelly tidak terlalu lembek sehingga mengurangi nilai sineresis/keluarnya air dari sistem dan panelis dapat merasakan kekenyalan jelly. Menurut Mahendradatta (2007) kekerasan tekstur gel semakin meningkat degan banyaknya karagenan yang ditambahkan.

\section{Pemilihan Perlakuan Terbaik}

Hasil pengujian terbaik jelly cincau hitam terhadap parameter kimia, fisik dan organoleptik dapat dilihat pada Tabel 2.

Tabel 2. Perlakuan Terbaik Kimia Fisik dan Organoleptik Jelly Cincau Hitam Akibat Perlakuan Konsentrasi Simplisia dan Konsentrasi Karagenan

\begin{tabular}{lccc}
\hline \multicolumn{1}{c}{ Perlakuan } & Kimia & Fisik & Organoleptik \\
\hline Simplisia cincau 0.5\% : karagenan 0.5\% & 0.3102 & 0.367 & 0.25 \\
Simplisia cincau 0.5\% : karagenan 0.75\% & 0.3291 & 0.334 & 0.18 \\
Simplisia cincau 0.5\% : karagenan 1\% & 0.2800 & 0.413 & 0.16 \\
Simplisia cincau 1\% : karagenan 0.5\% & 0.2202 & 0.381 & 0.21 \\
Simplisia cincau 1\% : karagenan 0.75\% & 0.2031 & 0.314 & 0.16 \\
Simplisia cincau 1\% : karagenan 1\% & 0.2078 & 0.270 & $0.12^{*}$ \\
Simplisia cincau 1.5\%: karagenan 0.5\% & $0.1660^{*}$ & 0.261 & 0.22 \\
Simplisia cincau 1.5\% : karagenan 0.75\% & 0.1847 & 0.255 & 0.21 \\
Simplisia cincau 1.5\% : karagenan 1\% & 0.1690 & $0.213^{*}$ & 0.17 \\
\hline
\end{tabular}

Keterangan: *merupakan hasil perlakuan terbaik

Pada uji kimia terlihat perlakuan terbaik pada jelly dengan konsentrasi simplisia 1.5\% dan konsentrasi karagenan $0.5 \%$. Sedangkan pada uji fisik terlihat perlakuan terbaik terletak pada jelly dengan konsentrasi simplisia $1.5 \%$ dan konsentrasi karagenan $1 \%$, dan pada uji organoleptik perlakuan terbaik didapatkan pada jelly dengan konsentrasi simplisia $1 \%$ dan konsentrasi karagenaan $1 \%$. Masing-masing pengujian memiliki hasil perlakuan terbaik yang berbeda-beda. 


\section{SIMPULAN}

Berdasarkan hasil penelitian yang telah dilakukan dapat disimpulkan bahwa, penambahan konsentrasi simplisia yang berbeda berpengaruh nyata $(\alpha=0.05)$ terhadap nilai $\mathrm{pH}$, total fenol, total pektin, dan nilai sineresis. Penambahan konsentrasi karagenan yang berbeda berpengaruh nyata $(\alpha=0.05)$ terhadap nilai total pektin dan nilai sineresis. Interaksi antara konsentrasi simplisia dan konsentrasi karagenan berpengaruh nyata terhadap aktivitas antioksidan, tekstur, nilai kecerahan $\left(\mathrm{L}^{*}\right)$, kemerahan $\left(\mathrm{A}^{*}\right)$ dan kekuningan $\left(\mathrm{B}^{*}\right)$. Pada analisis perlakuan terbaik didapatkan perakuan terbaik pengujian kimia pada jelly dengan konsentrasi simplisia $1.5 \%$ dan konsentrasi karagenan $0.5 \%$, pengujian fisik perlakuan terbaik terletak pada konsentrasi simplisia $1.5 \%$ dan konsentrasi karagenan $1 \%$, dan pada uji organoleptik perlakuan terbaik didapatkan pada jelly dengan konsentrasi simplisia $1 \%$ dan konsentrasi karagenaan $1 \%$.

\section{DAFTAR PUSTAKA}

Gunston, F. D. and F.B. Padley. 1997. Lipids Technologies and Applications. Marcel Dekker Inc. New York.

Hung, C. Y., and Yen, G. C. 2002. Antioxidant Activity of Phenolic Compound Isolated from Mesona Rocumbens Hemsl. J. Agric. Food Chem 50:10, 2993-2997

Lai, L-S, Chou, S-T and Chao, W-W. 2001. Studies on the antoixidative activities of HsianTsao (Mesona Procumbens Hemsl) Leaf Gum. J.Agric. Food Chem 49, 963-968.

Mahendratatta, M. 2007. Pangan Aman dan Sehat. Prasyarat Kebutuhan Mutlak Sehari-hari. Lembaga Penerbitan Universitas Hasanudin. Makasar.

Nuraini, D., Sunarto, P., dan Lucyana. 2000. Ekstraksi Komponen Pembentuk Gel Cincau Hitam dan Karakteristik Gelatinisasinya. BPPIHP. Bogor

Nusantoro, B. P. dan Haryadi. 2001. Pengaruh Jenis Pengekstrak dan Jenis Pati Terhadap Sifat Gel Cincau yang Dibuat degan Ekstraksi dan Pemasakan Optimal. Journal Agritech 18:4

Tasia, W. R. N. dan Widyaningsih, T. D. 2014. Potensi Cincau Hitam (Mesona Palustris BI.), Daun Pandan (Pandanus Amaryllifolius) dan Kayu Manis (Cinnamomum Burmannii) Sebagai Bahan Baku Minuman Herbal Fungsional. Skripsi. Universitas Brawijaya. Malang.

Wahyono, H., Fitriani, L., dan Widyaningsih, T. D. 2014. Potensi Cincau Hitam (Mesona Palustris BI.) Sebagai Pangan Fungsional Untuk Kesehatan: Kajian Pustaka. Skripsi. Universitas Brawijaya. Malang.

Wibowo, S. 1990. Budidaya Bawang Merah, Bawang Putih, dan Bawang Bombay. Penebar Swadaya. Jakarta

Winarno. 2002. Kimia Pangan dan Gizi. Gramedia Pustaka Utama. Jakarta

Zeleny, M. 1982. Mutiple Criteria Desition Making, $2^{\text {nd }}$ Edition. Mc Graw Hill. New York 